\title{
EFFECT OF FUN TEACHING METHODS USING FLASH CARD ON MOTIVATION AND LEARNING MATHEMATICS
}

\author{
lis Aisah \\ lis aisah@gmail.com \\ Tadris Matematika \\ Fakultas Ilmu Tarbiyah dan Keguruan \\ IAIN Syekh Nurjati Cirebon
}

\begin{abstract}
Teachers as a source of learning is obliged to provide a creative learning environment for students learning activities in the classroom. One of the teachers should do is pick and choose methods and media that will be used in learning activities. Less precise in selecting methods and learning media can be fatal to the students so that the students' motivation to learn mathematics to be low. Learning is packed with mood full of joy can motivate students to learn mathematics. The process of learning by playing eliminating pressures and boredom that learning activities can be run well. Fun bembelajaran teaching is a method that can make a pleasant atmosphere so that learning and teaching did not become monotonous and boring. Instructional media Flash cards is the right medium to help students / children remember and learn new information. In its implementation, the method fun teaching using instructional media flash card not only degan play or storytelling but the method fun teaching using instructional media flash card to make students become more creative, and the atmosphere of intimacy between students and teachers more closely so that the study of mathematics was not be a scary lesson for students. This study aimed to see whether fun method of teaching using instructional media flash card can affect motivation for mathematics students. And to know the students' motivation to learn math using Fun Teaching and learning media Flash Card. The research method used was experimental research design pretest-posttest control group design. The population in this study were all students in class VIII SMP Sindangjawa Academic Year 2013/2014 comprising four classes totaling 141 students. While the sampling technique used was simple random sampling technique by means raffle. The sample in this study was VIIIB class numbering 36 students as an experimental class and class VIIIC the 36 students as the control class. This study used questionnaires. Before analyzing the data, performed first prerequisite test analysis is the normality test and homogeneity test. Then proceed with the regression, coefficient of determination and significance test / t-test to look for the influence fun method of teaching using instructional media flash card on motivation to learn math students. Based on the results of the study, showed that the fun method of teaching using instructional media in learning math flash cards received good response. Motivation to learn mathematics students increased by 17.306. Data analysis techniques used in this study is a ttest, and based on the t-test is obtained t_hitung t_tabel $=6.151$ and 1.697. Based on the significant value of 5\%, which means t_hitung > t_tabel, thus $H \_0$ H_a rejected and accepted. So it can be concluded that there are significant fun method of teaching using instructional media flash card on motivation to learn math students.
\end{abstract}

Keywords: Fun Methods of Teaching, Learning Flash Media Card, Motivation Math

\section{Pendahuluan}

Upaya peningkatan Sumber Daya Manusia (SDM) yang berkualitas dapat melalui bidang pendidikan. Pendidikan sebagai pemegang peranan penting, karena pendidikan dapat 
mengembangkan kemampuan, meningkatkan mutu kehidupan dan martabat manusia. Pendidikan merupakan usaha sadar untuk menumbuhkembangkan potensi sumber daya manusia melalui kegiatan pembelajaran. Pada pendidikan formal, pelajaran matematika adalah salah satu mata pelajaran yang menduduki peran penting dalam pendidikan. Dilihat dari waktu yang digunakan dalam pendidikan formal, pelajaran matematika di sekolah lebih banyak dibandingkan dengan mata pelajaran lainnya. Serta pelaksanaan pendidikan diberikan pada semua jenjang pendidikan yang dimulai dari Sekolah Dasar (SD) sampai Menengah. Salah satu tujuan diberikannya matematika di jenjang pendidikan dasar dan menengah yaitu untuk mempersiapkan siswa agar dapat menggunakan matematika dan pola pikir matematika dalam kehidupan sehari-hari.1 Banyak kita jumpai siswa tidak tertarik mempelajari suatu materi, karena materi pelajaran tersebut menurutnya tidak menyenangkan. Ditambah dengan proses pembelajaran tersebut yang membosankan atau menjemukan, sehingga mengurangi motivasi belajar siswa dan menyebabkan prestasi belajar matematika belum menunjukkan hasil yang memuaskan. Hal ini dapat dilihat dari daftar nilai ulangan harian, nilai tugas, nilai tes semester, dan nilai ujian akhir nasional yang belum sesuai dengan harapan guru dan siswa. Keberhasilan belajar siswa dalam proses pembelajaran dipengaruhi oleh faktor internal dan eksternal. Dimana salah satu faktor internal tersebut adalah motivasi siswa itu sendiri. Dalam kegiatan belajar motivasi sangat diperlukan, sebab seseorang yang tidak mempunyai motivasi dalam belajar tidak mungkin akan melakukan aktivitas belajar. Pentingnya menjaga motivasi dalam proses belajar tidak dapat dipungkiri, karena dengan menggerakkan motivasi yang terpendam dan menjaganya dalam kegiatankegiatan yang dilaksanakan siswa akan menjadikan siswa itu lebih giat belajar. Selain faktor internal, faktor eksternal pun sangat mempengaruhi. Faktor eksternal yang sangat penting adalah guru, dimana guru harus berusaha untuk mencapai tujuan pembelajaran matematika di kelas. Dalam konsep pembelajaran, motivasi berarti seni mendorong peserta didik untuk melakukan kegiatan belajar sehingga tujuan pembelajaran tercapai. Pengertian ini sebetulnya lebih menekankan pada usaha guru untuk memberikan motivasi secara eksternal guna merangsang siswa agar lebih giat dalam belajar.2 Untuk menanggulangi problematika yang ada, guru matematika dituntut untuk dapat menjadikan pelajaran matematika lebih menarik dan disenangi oleh siswa. Guru harus bisa memberikan motivasi kepada siswa, bagaimana agar siswa tersebut tertarik dengan pembelajaran matematika. Tanpa adanya motivasi pada diri siswa tentunya mempelajari matematika itu akan sulit. Berbagai metode telah diterapkan demi menunjang kegiatan pembelajaran matematika di kelas, sehingga dapat meningkatkan motivasi belajar siswa. Inovasiinovasi baru yang menyenangkan, rileks, dan menarik dalam pembelajaran mutlak diperlukan, bahkan penggunaan media pembelajaran yang mencoba mengkonkretkan objek matematika yang abstrak pun dilakukan. Strategi meningkatkan motivasi belajar siswa sering menjadi masalah tersendiri bagi para guru. Terdapat banyak faktor, baik internal maupun eksternal yang mempengaruhi motivasi belajar siswa. Faktor internal yang mempengaruhi motivasi belajar siswa adalah siswa itu sendiri, sedangkan faktor eksternalnya adalah cara guru menyampaikan pelajaran matematika di kelas. Berdasarkan studi pendahuluan yang dilakukan penulis di SMP Sindangjawa pada hari kamis tanggal $24 \mathrm{Juli}$ 2014, menunjukkan bahwa banyak siswa kelas VIII yang mempunyai prestasi belajar matematika yang kurang bagus. Hal ini dapat dilihat dari nilai rapot matematika siswa yang rata-rata hanya mencapai nilai minimum sebesar70. Kurang bersemangatnya siswa dalam 
mengikuti pembelajaran matematika menjadi kendala utama minimnya prestasi belajar matematika siswa. Keberhasilan dalam pembelajaran merupakan harapan besar dari seorang manusia, baik ia sebagai siswa maupun sebagai seorang pendidik. Dalam mencapai tujuan pembelajaran diperlukan kerjasama antara pendidik dan peserta didik. Berdasarkan hasil wawancara yang dilakukan peneliti kepada siswa, yang menjadi salah satu kendala dalam pembelajaran matematika adalah materi bangun ruang. Masih banyak siswa yang mengalami kesulitan dalam memahami dan mengingat rumus-rumus bangun ruang yang beragam. Ketika siswa kesulitan dalam memahami dan mengingat rumus-rumus bangun ruang yang beragam, maka siswa menjadi sulit untuk mengerjakan soal-soal yang diberikan oleh guru dan akibatnya siswa menjadi malas untuk belajar, sehingga hasil belajar tidak memuaskan. Guru harus memilih dan mengorganisasi materi pelajaran tersebut agar siswa dapat lebih mudah memahami sebuah materi. Guru harus membuat suasana belajar di kelas menjadi menyenangkan dan lebih menarik, sehingga dapat meningkatkan motivasi belajar siswa. Suasana belajar yang menyenangkan dapat membuat siswa menjadi lebih fokus terhadap materi yang disampaikan. Guru sekurang-kurangnya dapat menggunakan alat peraga atau media pembelajaran yang murah dan efisien yang meskipun sederhana, tetapi merupakan suatu keharusan dalam upaya mencapai tujuan pembelajaran yang diharapkan. Untuk itu guru harus memiliki pengetahuan dan pemahaman yang cukup tentang metode dan media pembelajaran. Guru memerlukan media pembelajaran sebagai alat bantu dalam menyampaikan materi matematika agar siswa mampu menyerap materi matematika dengan baik. Guru harus menggunakan metode dan media pembelajaran yang terbaik untuk memfasilitasi pembelajaran atau peningkatkan pemahaman siswa terhadap materi yang disampaikan. Sebab proses untuk memfasilitasi pembelajaran bisa menjadi sebuah proses yang menantang, yang sering kali membutuhkan usaha-usaha kreatif untuk mencapai ragam tujuan-tujuan pembelajaran. Peranan guru sangat penting dalam proses belajar mengajar matematika. Guru berperan untuk menganalisis metode apa yang paling tepat agar proses pembelajaran dapat meningkatkan motivasi belajar siswa, tidak membosankan bahkan bisa menjadi menyenangkan dan bisa membuat siswa menyukai matematika. Peserta didik dapat belajar dengan mudah dan merasa senang dalam mengikuti proses pembelajaran dengan adanya metode dan media pembelajaran yang tepat. Biasanya peserta didik dapat dengan mudah dan cepat dalam menangkap materi pelajaran bila pembelajaran yang diselenggarakan tersebut menyenangkan, sehingga tujuan pembelajaran tersebut dapat tercapai. Oleh karena itu, kemampuan serta kesiapan guru dalam mengajar memegang peranan penting bagi keberhasilan proses belajar mengajar siswa.

Faktor-faktor yang mempengaruhi keberhasilan siswa diantaranya yaitu: kecerdasan siswa, kematangan siswa, motivasi siswa, minat siswa, metode pembelajaran yang disenangi siswa, sikap guru, kemampuan guru dan lingkungan masyarakat. Berdasarkan studi pendahuluan di SMP Sindangjawa pada hari kamis tanggal 24 Juli 2014, penulis menemukan banyak siswa kelas VIII yang mempunyai motivasi rendah dalam mengikuti pembelajaran matematika. Hal ini dapat diketahui dari hasil wawancara dengan guru SMP Sindangjawa yang menjelaskan bahwa siswa sering ribut di dalam kelas ketika pembelajaran matematika berlangsung. Untuk mengatasi permasalahan tersebut, maka pembelajaran matematika perlu diperbaiki guna meningkatkan motivasi belajar siswa. Untuk itu diperlukan solusi yang tepat untuk mengatasi masalah tersebut, sehingga diharapkan dapat meningkatkan motivasi belajar siswa. Metode 
Fun Teaching merupakan metode yang dapat dijadikan salah satu alternatif kegiatan belajar mengajar. Metode Fun Teaching mampu memberikan siswa yang mengikutinya dapat memahami materi yang diajarkan dengan cara menyeluruh dengan konsep pembelajaran yang menyenangkan dan menarik untuk diikuti, karena materi yang diajarkan melalui ice breaking, permainan, bercerita, sistem kelompok dengan suasana yang menyenangkan dan bergembira.3 Menurut Imam Maliki Ralibi sebagaimana dikutip oleh Muhaemin4 mengatakan bahwa "Fun teaching adalah salah satu metode pembelajaran yang menciptakan suasana belajar yang gembira dan menyenangkan. Bukan berarti menciptakan suasana glamour dan hura-hura. Tujuan kegembiraan disini adalah menciptakan suasana yang happy, membangkitkan minat (gairah untuk belajar atau motivasi), merangsang keterlibatan penuh serta menciptakan pemahaman atas materi yang dipelajari". Flash card adalah media yang tepat untuk membantu siswa/anak mengingat dan mempelajari informasi baru. Kartu ini mudah dibuat dan digunakan. Sebagian besar anakanak adalah visual learners dan kartu bergambar dengan warna-warna menarik bisa sangat bermanfaat untuk mengajar mereka.5 Metode Fun Teaching dapat kita padukan dengan media pembelajaran Flash Card untuk mendukung kegiatan pembelajaran matematika. Metode Fun Teaching dan penggunaan media pembelajaran Flash Card dalam pembelajaran matematika diharapkan dapat memberikan dan meningkatkan motivasi belajar matematika siswa, sehingga pembelajaran dapat berlangsung secara optimal. Berdasarkan latar belakang masalah yang telah diuraikan, maka permasalahan yang ada adalah kurang tepatnya penggunaan metode dan media pembelajaran sehingga perlu dilakukan perubahan. Apakah penerapan metode fun teaching dengan menggunakan media pembelajaran flash card berpengaruh terhadap motivasi belajar matematika siswa?

\section{Rumusan Masalah}

Berdasarkan pembatasan masalah yang telah diuraikan di atas, maka peneliti menetapkan perumusan masalah di atas yaitu :

1. Bagaimana respon siswa terhadap penerapan metode Fun Teaching dengan menggunakan media pembelajaran Flash Card?

2. Bagaimana motivasi belajar matematika siswa yang dalam pembelajarannya menerapkan metode konvensional (kelas kontrol) dan motivasi belajar matematika siswa yang dalam pembelajarannya menerapkan metode Fun Teaching dengan menggunakan media pembelajaran Flash Card (kelas eksperimen)?

3. Apakah penerapan metode Fun Teaching dengan menggunakan media pembelajaran Flash Card berpengaruh terhadap motivasi belajar matematika siswa?

\section{Tujuan Penelitian}

Berdasarkan perumusan masalah yang telah diuraikan di atas, penelitian ini bertujuan untuk

1. Mengetahui respon siswa terhadap penerapan metode Fun Teaching dengan menggunakan media pembelajaran Flash Card.

2. Mengetahui motivasi belajar matematika siswa yang dalam pembelajarannya menerapkan metode konvensional (kelas kontrol) dan motivasi belajar matematika 
siswa yang dalam pembelajarannya menerapkan metode Fun Teaching dengan menggunakan media pembelajaran Flash Card (kelas eksperimen).

3. Mengetahui pengaruh penerapan metode Fun Teaching dengan menggunakan media pembelajaran Flash Card terhadap motivasi belajar matematika siswa.

\section{Landasan Teori}

1. Pengertian Belajar

Sebagian besar ahli berpendapat bahwa belajar adalah proses perubahan, dimana perubahan tersebut merupakan hasil dari pengalaman. Dengan pengembangan tekhnologi informasi, belajar tidak hanya diartikan sebagai suatu tindakan terpisah dari kehidupan manusia. Banyak ilmuwan yang mengatakan belajar menurut sudut pandang mereka. Beberapa definisi belajar sebagai suatu perubahan menurut beberapa ahli adalah sebagai berikut.

1) Thorndike, salah seorang pendiri aliran teori belajar tingkah laku, mengemukakan bahwa belajar adalah proses interaksi antara stimulus (yang mungkin berupa pikiran, perasaan, atau gerakan) dan respons (yang juga bisa berupa pikiran, perasaan, atau gerakan). Jelasnya, menurut Thorndike, perubahan tingkah laku dapat berwujud sesuatu yang konkret (dapat diamati), atau yang nonkonkret (tidak bisa diamati). 6

2) Witherington mendefinisikan "belajar merupakan perubahan dalam kepribadian yang dimanifestikan sebagai pola-pola respon yang baru berbentuk keterampilan, sikap, kebiasaan, pengetahuan, dan kecakapan".7

3) Menurut Abu Ahmadi dan Joko Tri Prasetya8 belajar adalah proses perubahan perilaku berkat pengalaman dan pelatihan. Artinya tujuan kegiatan belajar ialah perubahan tingkah laku, baik yang menyangkut pengetahuan, keterampilan, sikap, bahkan meliputi segenap aspek pribadi.

4) Sedangkan Gage Berlinger dalam Evelin Siregar dan Hartini Nara9 mendefinisikan belajar sebagai suatu proses di mana suatu organisme berubah perilakunya sebagai akibat dari pengalaman.

5) Slameto10 mengemukakan bahwa, belajar ialah suatu proses usaha yang dilakukan oleh seseorang untuk memperoleh suatu perubahan tingkah laku yang baru secara keseluruhan, sebagai hasil pengalamannya sendiri dalam interaksi dengan lingkungannya.

6) Syaiful Bahri Djamarah dan Aswan Zain11 berpendapat bahwa: "Belajar adalah proses perubahan perilaku berkat pengalaman dan latihan". Artinya, tujuan kegiatan adalah perubahan tingkah laku, baik yang menyangkut pengetahuan, keterampilan maupun sikap, bahkan meliputi segenap aspek organisme atau pribadi.

7) Ernes ER. Hilgard dalam Yatim Riyanto12, mendefinisikan sebagai berikut : learning is the process by which an activity originates or is charged thought training procedures (whether in the laboratory or in the natural environments) as disitinguished from changes by factor not attributable to training. Artinya, (seseorang dapat dikatakan belajar kalau dapat melakukan sesuatu dengan cara latihan-latihan sehingga yang bersangkutan menjadi berubah).

8) Belajar adalah kegiatan yang berproses dan merupakan unsur yang sangat fundamental dalam setiap penyelenggaraan jenis dan jenjang pendidikan Dari beberapa 
definisi di atas maka penulis menyimpulkan bahwa belajar adalah suatu proses usaha aktif yang dilakukan oleh seseorang secara sengaja, berlangsung secara berkesinambungan, serta bertujuan untuk memperoleh perubahan pengetahuan, keterampilan, dan sikap yang positif serta relatif menetap sebagai pengalaman dalam berinteraksi dengan lingkungan (di dalam maupun di luar lembaga pendidikan) di mana individu itu berada.

\section{Motivasi Belajar Matematika}

Motivasi berasal dari Bahasa Latin "movere", yang berarti menggerakkan. Berdasarkan pengertian ini, makna motivasi menjadi berkembang.18 Motivasi adalah dorongan dasar yang menggerakkan seseorang bertingkah laku. Dorongan ini berada pada diri seseorang yang menggerakkan untuk melakukan sesuatu yang sesuai dengan dorongan dalam dirinya. Motivasi adalah kekuatan, baik dari dalam maupun dari luar yang mendorong seseorang untuk mencapai tujuan tertentu yang telah ditetapkan sebelumnya. Menurut Mc.Donald dalam Sardiman, A. M. motivasi adalah perubahan energi dalam diri seseorang yang ditandai dengan munculnya "feeling" dan didahului dengan tanggapan terhadap adanya tujuan. Dari pengertian yang dikemukakan Mc.Donald ini mengandung tiga elemen penting.

a) Bahwa motivasi itu mengawali terjadinya perubahan energi pada diri setiap individu manusia. Karena menyangkut perubahan energi manusia (walaupun motivasi itu muncul dari dalam diri manusia), penampakannya akan menyangkut kegiatan fisik manusia.

b) Motivasi ditandai dengan munculnya, rasa/ "feeling", afeksi seseorang. Dalam hal ini motivasi relevan dengan persoalan-persoalan kejiwaan, afeksi, dan emosi yang dapat menentukan tingkah laku manusia.

c) Motivasi akan dirangsang karena adanya tujuan. Jadi motivasi dalam hal ini sebenarnya merupakan respon dari suatu aksi, yakni tujuan. Motivasi menurut Sumadi Suryabrata dalam Djaali adalah keadaan yang terdapat dalam diri seseorang yang mendorongnya untuk melakukan aktivitas tertentu guna mencapai suatu tujuan. Sementara itu, Gates dan kawan-kawan mengemukakan bahwa motivasi adalah suatu kondisi fisiologis dan psikologis yang terdapat dalam diri seseorang yang mengatur tindakannya dengan cara tertentu. Motivasi ialah dorongan yang ada dalam diri seseorang untuk melakukan sesuatu dalam rangka memenuhi kebutuhannya. Motivasi memegang peranan penting dalam belajar, makin kuat motivasi seseorang dalam belajar, makin optimal dalam melakukan aktivitas belajar.22 Dari beberapa definisi di atas dapat disimpulkan bahwa motivasi adalah kondisi fisiologis dan psikologis yang terdapat dalam diri seseorang yang mendorongnya untuk melakukan aktifitas guna mencapai tujuan tertentu. Maka penulis menyimpulkan bahwa motivasi belajar matematika siswa adalah kekuatan yang terdapat dalam diri siswa sebagai pendorong atau penggerak siswa untuk melakukan kegiatan belajar matematika dan memberikan arah pada kegiatan belajar matematika tersebut untuk mencapai suatu tujuan belajar matematika, yaitu perubahan tingkah laku siswa meliputi kecakapan, kebiasaan, kepandaian, dan penguasaan ilmu pengetahuan. Motivasi dapat dibedakan menjadi motivasi intrinsik dan motivasi ekstrinsik, berikut penjelasan mengenai motivasi intrinsik dan motivasi ekstrinsik: a) Motivasi intrinsik Motivasi intrinsik adalah motif-motif yang menjadi aktif atau berfungsinya tidak perlu 
dirangsang dari luar, karena dalam diri setiap individu sudah ada dorongan untuk melakukan sesuatu. Sebagai contoh seseorang yang senang membaca, tidak usah ada yang menyuruh atau mendorongnya, ia sudah rajin mencari buku-buku untuk dibacanya. Kemudian kalau dilihat dari segi tujuan kegiatan yang dilakukannya (misalnya kegiatan belajar), maka yang dimaksud dengan motivasi intrinsik ini adalah ingin mencapai tujuan yang terkandung di dalam perbuatan belajar itu sendiri.23 Jenis motivasi ini timbul dari dalam individu sendiri tanpa ada paksaan dorongan orang lain. Motivasi ini sering disebut "motivasi murni", atau motivasi yang sebenarnya, yang timbul dari dalam diri siswa.24 Konsep motivasi intrinsik mengidentifikasikan tingkah laku seseorang yang merasa senang terhadap sesuatu; apabila ia menyenangi kegiatan itu, maka termotivasi untuk melakukan kegiatan tersebut. Jika seseorang menghadapi tantangan, dan ia merasa yakin dirinya mampu, maka biasanya orang tersebut akan mencoba melakukan kegiatan tersebut.25 Perlu diketahui bahwa siswa yang memiliki motivasi intrinsik akan memiliki tujuan menjadi orang yang terdidik, yang berpengetahuan, yang ahli dalam bidang studi tertentu. Satu-satunya jalan untuk menuju ke tujuan yang ingin dicapai ialah belajar, tanpa belajar tidak mungkin mendapat pengetahuan, tidak mungkin menjadi ahli. Dorongan yang menggerakkan itu bersumber pada suatu kebutuhan, kebutuhan yang berisikan keharusan untuk menjadi orang yang terdidik dan berpengetahuan.26 b) Motivasi ekstrinsik Motivasi ekstrinsik adalah motivasi yang berasal dari luar misalnya pemberian pujian, pemberian nilai sampai pada pemberian hadiah dan faktorfaktor eksternal lainnya yang memiliki daya dorong motivasional.27 Sebagai contoh seseorang itu belajar, karena tahu besok paginya akan ujian dengan harapan mendapatkan nilai baik, sehingga akan dipuji oleh pacarnya, atau temannya. Jadi yang penting bukan karena belajar ingin mengetahui sesuatu, tetapi ingin mendapatkan nilai yang baik, atau agar mendapat hadiah. Jadi kalau dilihat dari segi tujuan kegiatan yang dilakukannya, tidak secara langsung bergayut dengan esensi apa yang dilakukannya itu. Perlu ditegaskan, bukan berarti bahwa motivasi ekstrinsik ini tidak penting. Dalam kegiatan belajarmengajar tetap penting. Sebab kemungkinan besar keadaan siswa itu dinamis, berubahubah, dan juga mungkin komponen-komponen lain dalam proses belajar-mengajar ada yang kurang menarik bagi siswa, sehingga diperlukan motivasi ekstrinsik.28 Menurut Sardiman, A. M.29 ada beberapa bentuk dan cara untuk menumbuhkan motivasi dalam kegiatan belajar di sekolah. 1) Memberi angka Angka dalam hal ini sebagai simbol dari nilai kegiatan belajarnya. Banyak siswa belajar, yang utama justru untuk mencapai angka/nilai yang baik. Sehingga siswa biasanya yang dikejar adalah nilai ulangan atau nilai-nilai raport angkanya baikbaik. 2) Hadiah Hadiah dapat juga dikatakan sebagi motivasi, tetapi tidaklah selalu demikian. Karena hadiah untuk suatu pekerjaan, mungkin tidak akan menarik bagi seseorang yang tidak senang dan tidak berbakat untuk suatu pekerjaan tersebut. 3) Saingan/kompetisi Saingan atau kompetisi dapat digunakan sebagai alat motivasi untuk mendorong belajar siswa. Persaingan, baik persaingan individual maupun persaingan kelompok dapat meningkatkan prestasi belajar siswa. 4) Ego-involvement Menumbuhkan kesadaran kepada siswa agar merasakan pentingnya tugas dan menerimanya sebagai tantangan sehingga bekerja keras dengan mempertaruhkan harga diri, adalah sebagai salah bentuk motivasi yang cukup penting. 5) Memberi ulangan Para siswa akan menjadi giat belajar kalau mengetahui akan ada 
ulangan. Oleh karena itu memberi ulangan ini juga merupakan motivasi. 6) Mengetahui hasil Dengan mengetahui hasil pekerjaan, apalagi kalau terjadi kemajuan, akan mendorong siswa untuk lebih giat belajar. Semakin mengetahui bahwa hasil belajar meningkat, maka ada motivasi pada diri siswa untuk terus belajar, dengan suatu harapan hasilnya terus meningkat. 7) Pujian Apabila ada siswa yang sukses dan berhasil menyelesaikan tugas dengan baik, perlu diberikan pujian. Pujian ini adalah bentuk reinforcement yang positif dan sekaligus merupakan motivasi yang baik. 8) Hukuman Hukuman sebagai reinforcement yang negatif tetapi kalau diberikan secara tepat dan bijak bisa menjadi alat motivasi. 9) Hasrat untuk belajar Hasrat untuk belajar, berarti ada unsur kesengajaan, ada maksud untuk belajar. 10) Minat 11) Tujuan yang diakui Rumusan tujuan yang diakui dan diterima baik oleh siswa, merupakan alat motivasi yang sangat penting. Sebab dengan memahami tujuan yang harus dicapai, karena dirasa sangat berguna dan menguntungkan, maka akan timbul gairah untuk terus belajar.

\section{Metode pembelajaran Fun Teaching dengan menggunakan media pembelajaran Flash Card}

Metode berasal dari bahasa Yunani yaitu "methodos" yang berarti cara atau jalan yang ditempuh. Metode adalah cara yang digunakan untuk mengimplementasikan rencana yang sudah disusun dalam kegiatan nyata agar tujuan yang telah disusun tercapai dengan optimal

\section{Pembahasan}

Penelitian ini menggunakan metode eksperimen, di mana peneliti terlibat langsung dalam proses belajar mengajar dengan menggunakan metode fun teaching dan media pembelajaran flash card. Belajar dengan metode fun teaching dengan menggunakan media pembelajaran flash card merupakan pengalaman yang baru bagi siswa, sehingga dapat lebih menarik perhatian siswa. Hal ini merupakan modal dasar untuk menumbuhkan motivasi belajar matematika siswa. Motivasi belajar dapat timbul karena faktor intrinsik, berupa hasrat dan keinginan berhasil dan dorongan kebutuhan belajar, harapan akan cita-cita. Sedangkan faktor ekstrinsiknya ialah adanya penghargaan, lingkungan belajar yang kondusif, dan kegiatan belajar yang menarik. Kedua faktor tersebut disebabkan oleh rangsangan tertentu, sehingga seseorang berkeinginan untuk melakukan aktifitas belajar yang lebih giat dan semangat. Anggapan siswa mengenai matematika menjadi salah satu pelajaran yang sulit dapat menimbulkan motivasi belajar matematika siswa yang rendah. Hal tersebut tentu akan berpengaruh juga pada prestasi belajar matematika yang akan diperoleh. Untuk itu, diperlukan inovasi dan variasi metode dan media pembelajaran yang dapat merubah anggapan motivasi belajar matematika siswa yang rendah. Penerapan metode dan media pembelajaran yang tepat dapat memberikan rasa nyaman dan senang kepada siswa dalam proses pembelajaran. Ditambah dengan melibatkan siswa secara aktif dalam pembelajaran dapat menumbuhkan sikap belajar yang positif pada pembelajaran matematika. Keinginan siswa untuk belajar matematika yang tumbuh akibat dari metode dan media pembelajaran yang diterapkan guru dalam proses pembelajaran akan mempengaruhi motivasi belajar matematika siswa. Salah satu metode dan media pembelajaran yang menurut peneliti sesuai dengan hal tersebut adalah metode fun teaching dengan menggunakan media pembelajaran 
flash card. Dalam tahapan-tahapan tersebut menekankan pada keaktifan siswa dalam proses pembelajaran, serta memperhatikan pengetahuan awal siswa untuk kemudian menemukan pengetahuan baru. Dengan menerapkan metode fun teaching dengan menggunakan media pembelajaran flash card dalam pembelajaran matematika diharapkan dapat menumbuhkan motivasi belajar matematika siswa yang positif. Adanya motivasi belajar matematika siswa tersebut membuat siswa menjadi lebih aktif dan tekun pada proses pembelajarannya. Dalam penelitian peneliti memberikan perlakuan dengan metode yang berbeda kepada dua kelas yang berbeda sebagai kelas kontrol dan kelas eksperimen. Peneliti memberikan perlakuan kepada kelas eksperimen yaitu di kelas VIIIB SMP Sindangjawa dengan menerapkan metode fun teaching dengan menggunakan media pembelajaran flash card dalam pembelajaran matematika selama 3x pertemuan/perlakuan. Sedangkan di kelas kontrol yaitu di kelas VIIIC SMP Sindangjawa peneliti memberikan perlakuan dengan menerapkan metode konvensional dalam pembelajaran matematika selama $3 x$ pertemuan/perlakuan. Sebelum diberikan perlakuan peneliti menyebarkan angket motivasi belajar matematika siswa kepada kelas kontrol dan kelas eksperimen sebagai pretest untuk mengetahui seberapa besar motivasi belajar matematika siswa. Kemudian setelah diberikan perlakuan peneliti menyebarkan angket di kelas kontrol (VIIIC) dan kelas eksperimen (VIIIB) SMP Sindangjawa yaitu berupa angket motivasi belajar matematika siswa sebagai post test untuk mengetahui seberapa besar motivasi belajar matematika siswa setelah diberikan perlakuan. Sebelum angket disebarkan kepada siswa untuk pretest dan post test angket motivasi belajar matematika siswa sudah diuji cobakan di kelas VIIIA SMP Sindangjawa untuk mengetahui validitas dan reliabilitas dari angket tersebut. Untuk kelas eksperimen peneliti menyebarkan angket respon metode fun teaching dengan menggunakan media pembelajaran flash card sebagai pendukung atau penguat hasil penelitian. Angket respon tersebut disebarkan setelah perlakuan, siswa mengisi angket tersebut sesuai dengan pengalaman belajarnya selama menggunakan metode fun teaching dengan menggunakan media pembelajaran flash card. Dari hasil analisis deskripsi data dapat disimpulkan setelah dilakukan penelitian mengenai pengaruh metode fun teaching dengan menggunakan media pembelajaran flash card terhadap motivasi belajar matematika siswa yang dilaksanakan di SMP Sindangjawa, didapat dua kelompok data yaitu dari kelas kontrol dan kelas eksperimen. Kedua data tersebut kemudian diolah dan dianalisis menurut prosedur yang telah dijalaskan di bab sebelumnya. Berdasarkan hasil analisis data, diketahui bahwa terdapat perbedaan motivasi belajar siswa antara siswa yang mendapat pembelajaran dengan metode konvensional (kelas kontrol) dengan siswa yang mendapat pembelajaran dengan metode fun teaching dengan menggunakan media pembelajaran flash card (kelas eksperimen). Untuk mengetahui perlakuan mana yang lebih baik, dapat dilihat dengan cara membandingkan skor rata-rata motivasi belajar siswa dari dua kelompok tersebut. Skor Rata-rata Motivasi Belajar

Kelas

Skor Motivasi Belajar Matematika Kontrol 58,083 Eksperimen 75,389

Berdasarkan Tabel 4.29 terlihat bahwa rata-rata skor motivasi belajar matematika siswa yang diperoleh kelas eksperimen lebih tinggi dibandingkan dengan kelas kontrol. Hal tersebut mendeskripsikan bahwa metode fun teaching dengan menggunakan media pembelajaran flash card memberikan konstribusi yang cukup signifikan dalam meningkatkan motivasi belajar matematika siswa. Hal ini dapat diperkuat dari hasil angket respon terhadap metode 
fun teaching dengan menggunakan media pembelajaran flash card yang disebarkan ke kelas eksperimen. Pada Tabel indikator pertama ratarata siswa menyatakan bahwa mereka lebih menyukai pembelajaran matematika dengan metode Fun Teaching dan media pembelajaran Flash Card daripada metode pembelajaran yang lain adalah sebesar 83,333\% termasuk dalam kategori sangat tinggi. Pada Tabel indikator ke dua rata-rata siswa menyatakan bahwa mereka lebih rajin dan aktif jika penyampaian materi matematika dengan metode Fun Teaching dan media pembelajaran Flash Card adalah sebesar 93,981\% termasuk dalam kategori sangat tinggi. Pada Tabel 4.17 indikator ke tiga rata-rata siswa menyatakan bahwa mereka lebih semangat dalam pembelajaran matematika menggunakan metode fun teaching dan media pembelajaran flash card adalah sebesar $89,259 \%$ termasuk dalam kategori sangat tinggi. Setelah peneliti mendapatkan data angket dari siswa tersebut, peneliti melakukan analisis data dengan bantuan software SPSS 18,0 yaitu untuk menghitung uji normalitas, uji homogenitas, uji kelinieran regresi, dan uji hipotesis. Uji normalitas dengan bantuan software SPSS 18,0 menggunakan rumus Kolmogorov-Smirnov didapat nilai (Sig. 0,200 dan sig. 0,200). Dengan taraf nyata $\alpha=0,050$ maka disimpulkan semuanya $>0,050$, artinya data angket tersebut berdistribusi secara normal. Uji homogenitas dengan bantuan software SPSS 18,0 dapat diketahui bahwa nilai sig. sampel semuanya berada di atas $0,050(0,235>0,050)$ dengan demikian dapat disimpulkan bahwa data tersebut berdistribusi homogen. Dan uji kelinieran regresi diperoleh nilai sig.0,000. Dan 0,000 <0,050, sehingga dapat disimpulkan regresi bersifat linier. Hal ini menunjukkan model regresi linear dapat digunakan. Didapat persamaan regeresi $=-3,695+0,732 X$, dengan koefisien korelasi sebesar 0,743 didapat

sedangkan taraf signifikansi didapat .Jadi atau $6,151>1,697$, maka tolak dan terima. Sehingga dapat disimpulkan bahwa terdapat pengaruh metode Fun Teaching dengan menggunakan media pembelajaran Flash Card terhadap motivasi belajar matematika siswa sebesar 55,2\%.

\section{Kesimpulan}

Berdasarkan tujuan, pengolahan data, dan hasil penelitian mengenai pengaruh metode Fun Teaching dengan menggunakan media pembelajaran Flash Card terhadap motivasi belajar matematika siswa serta hasil pembahasan dan pengujian hipotesis, diperoleh kesimpulan sebagai berikut:

1. Respon siswa terhadap penerapan metode fun teaching dengan menggunakan media pembelajaran flash card menunjukkan respon yang positif. Dari data yang diperoleh dalam kegiatan pembelajaran dapat diketahui bahwa rata-rata skor respon siswa terhadap penerapan metode fun teaching dengan menggunakan media pembelajaran flash card yaitu sebesar 107,97 artinya rata-rata respon siswa termasuk dalam kategori baik. Hal ini dapat dilihat dari Tabel 4.15 rata-rata siswa menyatakan bahwa mereka lebih menyukai pembelajaran matematika dengan menerapkan metode Fun Teaching dengan menggunakan media pembelajaran Flash Card dari pada metode pembelajaran yang lain adalah sebesar $83,333 \%$ termasuk dalam kategori sangat tinggi. Jadi siswa lebih menyukai pembelajaran dengan menerapkan metode Fun Teaching dengan menggunakan media pembelajaran Flash Card dari pada metode pembelajaran yang lain karena metode fun teaching dan media pembelajaran flash card menciptakan suasana belajar yang gembira dan menyenangkan, belajar 
matematika lebih menarik dan mudah dipahami, serta tidak membuat bingung dalam belajar matematika, sehingga memotivasi siswa untuk belajar matematika.

2. Motivasi belajar matematika siswa kelas VIIIB (Kelas eksperimen) dan kelas VIIIC (Kelas kontrol) di SMP Sindangjawa setelah diberikan perlakuan dengan menerapkan metode fun teaching dengan menggunakan media pembelajaran flash card dan metode konvensional menjadi lebih tinggi. Hal ini dapat dilihat dari skor rata-rata motivasi belajar matematika siswa yang mengalami kenaikan skor sebasar 7,222 pada kelas kontrol dan 23,5 pada kelas eksperimen. Dari hasil penelitian dapat disimpulkan bahwa skor rata-rata siswa yang dalam pembelajarannya menerapkan metode konvensional (kelas kontrol) berbeda dengan skor rata-rata siswa yang dalam pembelajarannya menerapkan metode Fun Teaching dengan menggunakan media pembelajaran Flash Card (kelas eksperimen). Siswa yang dalam pembelajarannya menerapkan metode Fun Teaching dengan menggunakan media pembelajaran Flash Card lebih baik dari pada siswa yang dalam pembelajarannya menerapkan metode konvensional. Hal ini dapat dilihat dari skor rata-rata angket siswa kelas kontrol sebesar 58,083 dan untuk kelas eksperimen sebesar 75,389. Dari data skor rata-rata kelas terlihat jelas perbedaan motivasi belajar matematika siswa antara kelas kontrol yang menerapkan metode konvensional dan kelas eksperimen yang menerapkan metode fun teaching dengan menggunakan media pembelajaran flash card sebesar 17,306 .

3. Berdasarkan hasil perhitungan $r$ korelasi yaitu uji signifikansi didapatkan, sedangkan taraf signifikansi didapat Hal ini menunjukkan atau 6,151 $>1,697$, maka tolak dan terima . Sehingga dapat disimpulkan bahwa terdapat pengaruh yang signifikan penerapan metode Fun Teaching dengan menggunakan media pembelajaran Flash Card terhadap motivasi belajar matematika siswa sebesar $55,2 \%$ dan sisanya dipengaruhi oleh faktor lain.

\section{Pustaka}

- Ahmadi, Abu dan Joko Tri Prasetya. 2005. SBM (Strategi Belajar Mengajar). Bandung: Pustaka Setia.

- Ahmadi, lif Khiru dan Sofan Amri. 2010. Strategi Pembelajaran Sekolah Berstandar Internasional dan Nasional. Jakarta: PT.Prestasi Pustakaraya.

- Arikunto, Suharsimi. 2002. Prosedur Penelitian Suatu Pendekatan Praktek. Jakarta: PT. Rineka Cipta.

- Aripin, Ipin. 2013. Modul Pelatihan Teknik Pengolahan Data dengan Excel \& SPSS. Tidak diterbitkan. Cirebon:IAIN Syekh Nurjati,

- Arsyad, Azhar. 2011. Media Pembelajaran. Jakarta: PT.Raja Grafindo Persada

- Baskoro, Edi Prio. 2008. Media Pembelajaran. Cirebon: Swagati Press.

- Damayanti, Deni. 2013. Panduan Lengkap Menyusun Proposal, Skripsi, Tesis, Disertasi untuk Semua Program Studi. Yogyakarta: Araska.

- Darmansyah. 2011. Strategi Pembelajaran Menyenangkan dengan Humor. Jakarta: PT.Bumi Aksara. Djaali. 2008. Psikologi Pendidikan. Jakarta: Bumin Aksara. 
- Djamarah, Syaiful Bahri dan Aswan Zain. 1997. Strategi Belajar Mengajar. Jakarta: Rineka Cipta.

- E.T. Ruseffendi. 2006. Pengentar Kepada Membantu Mengembangkan Kompetensi dalam Pengajaran Matematika untuk meningkatkan CSBA. Bandung: Tarsito.

- Hariwijaya dan Triton. 2011. Pedoman Penulisan Ilmiah Skripsi \& Tesis. Jakarta Selatan: PT.Suka Buku.

- Harwijaya. 2009. Meningkatkan Kecerdasan Matematika. Yogyakarta: Tugu Publiser. Hasan, M. Iqbal. 2002. Pokok-pokok Materi Metodologi Penelitian dan Aplikasinya. Bogor: Ghalia Indonesia.

- Hasanah, lis. 2012. Pengaruh Pembelajaran dengan Pendekatan "SAVI" terhadap Motivasi Belajar Matematika Siswa (Studi pada Siswa Kelas VII SMP Negeri 2 Sumber Kabupaten Cirebon). Skripsi. Tidak diterbitkan. Cirebon: IAIN Syekh Nurjati.

- Indriana, Dina. 2011. Ragam Alat Bantu Media Pengajaran. Jogjakarta: Diva Press.

- Kustandi, Cecep dan Bambang Sutjipto. 2011. Media Pembelajaran Manual dan Digital. Bogor: Ghalia Press.

- Lestari, Tria. 2011. Pengaruh Pemanfaatan Sarana Dan Prasarana Pendidikan Terhadap Motivasi Belajar Matematika Siswa SMP Negeri 2 Mandirancan Kabupaten Kuningan. Skripsi. Tidak diterbitkan. Cirebon: IAIN Syekh Nurjati. 